\title{
Tetracapsuloides bryosalmonae and PKD in juvenile wild salmonids in Denmark
}

\author{
Alf Skovgaard*, Kurt Buchmann \\ Department of Veterinary Disease Biology, Faculty of Life Sciences, University of Copenhagen, Denmark
}

\begin{abstract}
The myxozoan Tetracapsuloides bryosalmonae is the causative agent of proliferative kidney disease (PKD), a widespread and serious condition in salmonid fishes in Europe and North America. In Europe, PKD is primarily reported affecting farmed rainbow trout Oncorhynchus mykiss, but limited information exists on the occurrence and effects of $T$. bryosalmonae in wild salmonids. We investigated the presence of T. bryosalmonae in salmonids in Denmark and found that the parasite is common in the dominant wild Danish salmonid, brown trout Salmo trutta, and that it also appears in wild Atlantic salmon S. salar. Clinical signs of PKD were present in some brown trout, but in most cases the parasite was found through histology and/or PCR investigations of kidney tissue in fish that showed no signs of infection. Even though there was high similarity between internal transcribed spacer 1 (ITS1) sequences of $T$. bryosalmonae from wild brown trout, Atlantic salmon and farmed rainbow trout, a geographic pattern was indicated among T. bryosalmonae ITS1 phylotypes. None of the investigated streams were found free of $T$. bryosalmonae, but prevalence of the parasite was highly variable.
\end{abstract}

KEY WORDS: Salmo trutta $\cdot$ Salmo salar $\cdot$ Oncorhynchus mykiss $\cdot$ Tetracapsuloides bryosalmonae

\section{INTRODUCTION}

Proliferative kidney disease (PKD) is a common, parasite-induced condition with serious effects on the production of salmonids in freshwater aquaculture in Europe and North America (Clifton-Hadley et al. 1984, Hedrick et al. 1993). The disease was first detected in the late 1970s, but retrospectively, it has been argued that disease conditions reported early in the 20th century in salmonid fish from Northern Europe may have represented the first observations on PKD (Clifton-Hadley et al. 1984, Hedrick et al. 1993). PKD is caused by the parasite Tetracapsuloides bryosalmonae (Myxozoa: Malacosporea) (Anderson et al. 1999, Canning et al. 2002), which has a life cycle that includes species of freshwater bryozoans (Canning et al. 1999, 2002, Longshaw et al. 1999). In fish farms with no or limited inflow of natural freshwater, it should thus be possible to avoid intake of $T$. bryosalmonae spores and subsequent problems with PKD. While a number of salmonid fish (genera Oncorhynchus, Thymallus, Salmo and Salvelinus) are susceptible to infection (Table 1), it is chiefly European freshwater rainbow trout farms that rely on inflow of stream water which have suffered from economic losses due to PKD (Hedrick et al. 1993).

Clinical signs related to PKD include a darkened body, pale gills, abdominal distension, exophthalmia, ascites, a grossly enlarged kidney and splenomegaly (Hedrick et al. 1993). The infection causes a severe immunological response through the proliferation of parasite cells in the kidney (Clifton-Hadley et al. 1984, Hedrick et al. 1993). A heavily swollen and discoloured/pale kidney is often used as an indication of PKD, but specific diagnostic characteristics are the detection of parasite cells in fish (kidney) tissue through histological examination. Outbreak of PKD 
Table 1. Fish species known to host Tetracapsuloides bryosalmonae

\begin{tabular}{|c|c|}
\hline Host species & First reference \\
\hline \multicolumn{2}{|l|}{ Salmonids } \\
\hline Salmo salar, Atlantic salmon & Ellis et al. (1982) \\
\hline S. trutta, brown trout & Seagrave et al. (1981) \\
\hline S. trutta marmoratus, marble trout & Beraldo et al. (2006) \\
\hline Oncorhynchus clarki, cutthroat trout & MacConnell \& Peterson (1992) \\
\hline O. gorbuscha, pink salmon & Braden et al. (2010) \\
\hline O. kisutch, coho salmon & Hedrick et al. (1984) \\
\hline O. mykiss, rainbow trout & Roberts \& Shepherd $(1974)^{a}$ \\
\hline O. mykiss aguabonita, golden trout & Morris et al. (2003) \\
\hline O. nerka, kokanee & Arkush \& Hedrick (1990) \\
\hline O. tshawytscha, chinook salmon & Hedrick et al. (1984) \\
\hline Salvelinus alpinus, Arctic char & Bucke et al. (1991) \\
\hline S. fontinalis, brook trout & Feist \& Bucke (1993) $)^{a, b}$ \\
\hline Thymallus thymallus, grayling & Seagrave et al. (1981) \\
\hline \multicolumn{2}{|l|}{ Non-salmonids } \\
\hline Esox lucius, Northern pike ${ }^{\mathrm{c}}$ & Seagrave et al. (1981) \\
\hline \multicolumn{2}{|c|}{$\begin{array}{l}\text { aEarlier observations on kidney abnormalities may have been caused by } \\
\text { PKD as discussed by Clifton-Hadley et al. (1984) }\end{array}$} \\
\hline \multicolumn{2}{|c|}{$\begin{array}{l}\text { 'Infection in } S \text {. fontinalis has not been confirmed, but parasite cells injected } \\
\text { into the fish appeared to be infective and undergo sporogony (Feist \& } \\
\text { Bucke 1993) }\end{array}$} \\
\hline \multicolumn{2}{|c|}{$\begin{array}{l}\text { 'May have been confused with another myxozoan (Grabner \& El-Matbouli } \\
\text { 2008) }\end{array}$} \\
\hline
\end{tabular}

populations of salmonid fishes both in North America and in Europe. The presence of $T$. bryosalmonae has been demonstrated in wild fish through histological observations of parasite cells (Hedrick et al. 1993, Braden et al. 2010), by PCR and sequencing (Sterud et al. 2007), and in addition, wild fish with pathological signs corresponding to PKD have been reported (Wootten \& McVicar 1982, Bucke et al. 1991, Feist \& Bucke 1993, Sterud et al. 2007). Yet, the impact of PKD on wild fish is a matter of some uncertainty because the effect of PKD on wild fish populations has not been adequately documented. At some European localities, it has been concluded that PKD is responsible for high mortality in wild brown trout Salmo trutta (Wahli et al. 2002, 2007) and Atlantic salmon $S$. salar (Sterud et al. 2007). Even though this is probable, it is difficult, however, to prove with certainty that PKD is the only cause of the observed mortalities.

is seasonal with temperature dependence of life cycle of the parasite as well as of signs of the infection, and in general, clinical infections occur at temperatures above $15^{\circ} \mathrm{C}$ (Hedrick et al. 1993, Tops et al. 2006). Mortality rates due to PKD are variable and can, in particular, be high when secondary infections are involved. There is currently no licensed medical treatment for PKD. However, it is possible to avoid introduction of the parasite to a fish farm by not using stream water in the farm, and furthermore, signs of PKD may be minimized through management practice (Ferguson 1981).

While the occurrence and effects of Tetracapsuloides bryosalmonae infections in farmed fish is well documented, considerably less is known about the implications of this parasite for wild fish populations (Peeler et al. 2008, Okamura et al. 2011). Intuitively, T. bryosalmonae is most probably common in natural freshwater habitats, since its bryozoan hosts are widespread in nature (Wiebach 1960, Wood 2002), and PKD is being found in more and more fish populations of salmonids, but so far only in freshwater (Sterud et al. 2007, Kristmundsson et al. 2010). Furthermore, infections in farmed fish are thought to originate from the environment, i.e. from bryozoan hosts, and the possibility exists that $T$. bryosalmonae is prevalent in wild salmonids. Investigations have confirmed infections with $T$. bryosalmonae in wild
In Denmark, PKD has been observed regularly in rainbow trout Oncorhynchus mykiss in fish farms on the Jutland peninsula since 1982 (Olesen 1984, Buchmann et al. 1995, Buchmann \& Bresciani 1997), and problems due to PKD appear to be restricted to certain fish farms or geographic areas. So far, the disease has been reported only from rainbow trout farms. However, brown trout is common in streams and rivers in Denmark, and several other salmonids, e.g. Atlantic salmon, are present though less common. Also, the potential invertebrate hosts of $T$. bryosalmonae are considered to be widespread in Danish freshwater ecosystems (Marcus 1940), indicating that environmental conditions are suitable for $T$. bryosalmonae. So far, there is no information available on the occurrence of $T$. bryosalmonae in wild fish in Denmark, and the aim of the present work is to investigate the possible existence of this parasite in wild Danish salmonids.

\section{MATERIALS AND METHODS}

\section{Sampling, autopsy, and histology}

Young of the year $(0+)$ juveniles of brown trout were sampled by electrofishing in 5 minor freshwater streams in Denmark (Fig. 1) in late October and early 


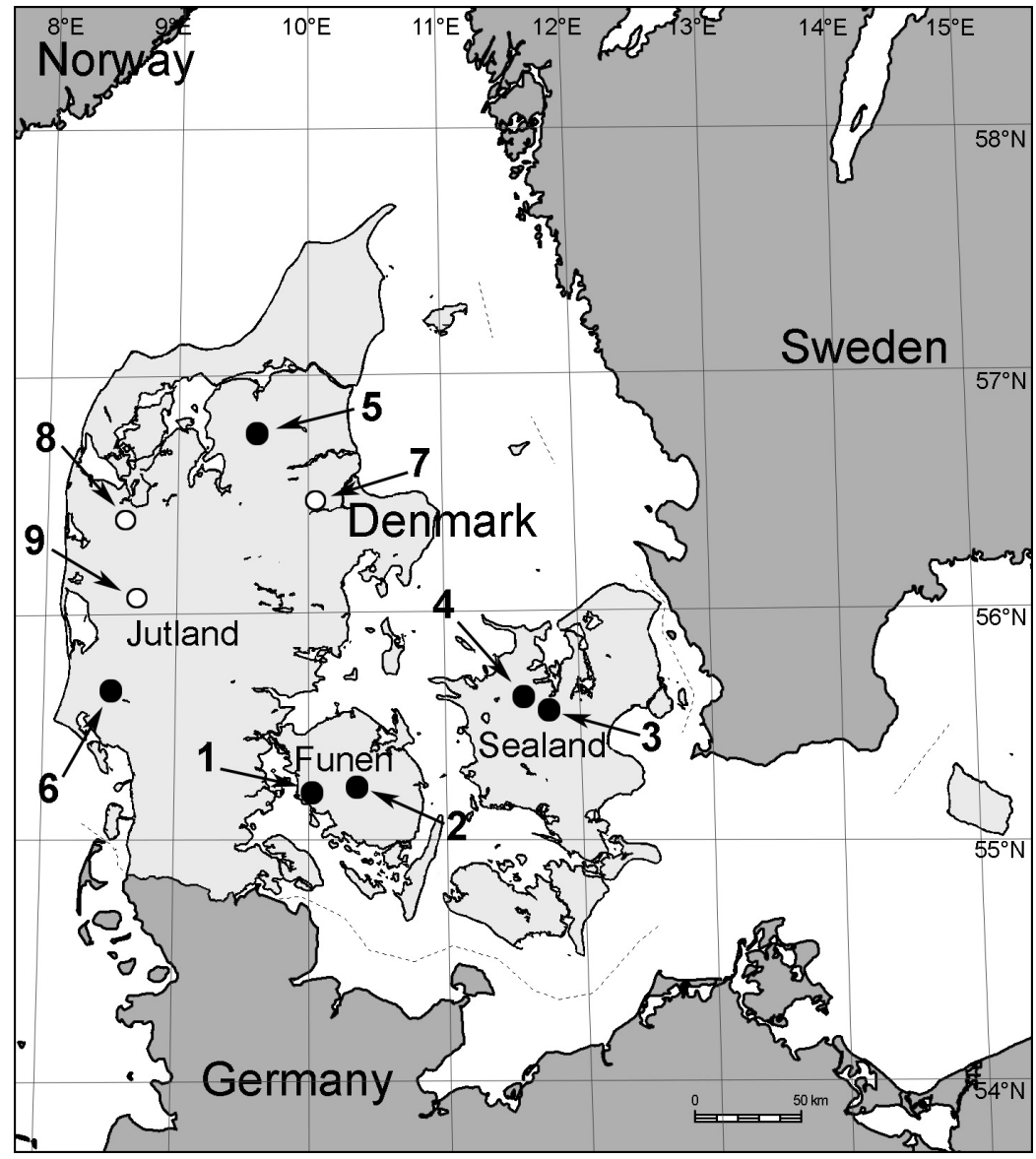

Fig. 1. Sampling sites. Wild caught fish (๑). Salmo trutta from the streams: 1 , $\mathrm{Aa}_{\text {; }}$ 2, Lindved; 3, Elverdam; 4, Kalvemose; 5, Sillevad. S. salar from the river: 6, Varde. Oncorhynchus mykiss farms (O)

November 2008 and 2009. Water temperature was 8 to $10^{\circ} \mathrm{C}$. A total of 112 brown trout were sampled at the following sites: 20 fish from the stream Elverdam on the central part of the island of Sealand $\left(55.63581^{\circ} \mathrm{N}, 11.79367^{\circ} \mathrm{E}\right), 20$ from the stream Kalvemose (central Sealand, $55.69313^{\circ} \mathrm{N}, 11.63358^{\circ} \mathrm{E}$ ), 27 from the stream Lindved on the central part of the island of Funen $\left(55.38405^{\circ} \mathrm{N}, 10.45429^{\circ} \mathrm{E}\right), 20$ from the stream Aa (southern Funen, $55.21468^{\circ} \mathrm{N}$, $9.98383^{\circ} \mathrm{E}$ ), and 25 from the stream Sillevad (northern part of the Jutland peninsula, $56.82245^{\circ} \mathrm{N}$, $\left.9.55396^{\circ} \mathrm{E}\right)$.

Fish were brought live to the lab and investigated for external signs of PKD (streams Elverdam, Kalvemose, Lindved, and Aa). Fish were then anesthetized, euthanized and autopsied. Duplicate parts of the head kidney were put into (1) $4 \%$ neutralbuffered formalin for $24 \mathrm{~h}$ for histology and (2) $70 \%$ ethanol for DNA extraction. On one occasion, no sample was preserved in formalin; instead the fish were killed, cut open and the entire fish preserved in $70 \%$ ethanol (the stream Sillevad).

In addition to brown trout, 31 ethanol-preserved Atlantic salmon $(0+)$ were investigated for Tetracapsuloides bryosalmonae infection by PCR. These fish were collected from the river Varde during a previous study (Von Gersdorff Jørgensen et al. 2008). Juvenile rainbow trout $(n=37)$ were collected from 3 freshwater fish farms which had been reported as having PKD outbreaks peaking 2 to $3 \mathrm{wk}$ prior to sampling. These fish farms are fed by 3 different river systems and are, therefore, not physically connected. The rainbow trout served as positive controls for both PCR and histology. Two negative controls, i.e. kidney tissue from $0+$ brown trout juveniles that had never been exposed to $T$. bryosalmonae infection, were obtained from a tap water-fed trout hatchery located in northern Sealand (Esrum Monastery near the river Esrum).

\section{Lectin histochemistry}

Lectin histochemical staining of Tetracapsuloides bryosalmonae cells was performed following a previously published protocol (Castagnaro et al. 1991) with a few simplifications: paraffin-embedded kidney sections were deparaffinised and gradually transferred to distilled water, and endogenous peroxidise activity was then blocked by incubating kidney sections in $3 \% \mathrm{H}_{2} \mathrm{O}_{2}$ in phosphate-buffered saline (PBS) for $10 \mathrm{~min}$ at room temperature. The slides were rinsed for $5 \mathrm{~min}$ in tap water, and kidney sections were covered with $30 \mu \mathrm{g}$ $\mathrm{ml}^{-1}$ biotinylated Griffonia simplicifolia lectin (BS-I, Sigma L-3759) for $1 \mathrm{~h}$ in a moist chamber. After rinses with PBS, sections were covered by an avidin-biotin peroxidase complex $(\mathrm{ABC})$ following the manufacturer's instruction (Vector Lab). Following 2 more rinses, sections were coloured by staining for $10 \mathrm{~min}$ with an AEC solution (0.03\% AEC [3-amino-9-ethylcarbazole] in $0.05 \mathrm{M}$ acetic acid [pH 5.0] with $0.01 \%$ $\mathrm{H}_{2} \mathrm{O}_{2}$, final concentrations). Slides were finally counterstained with Meyer's haematoxylin and mounted with Aquamount (Gurr, BDH Chemicals). 


\section{Detection of Tetracapsuloides bryosalmonae by PCR}

The presence of Tetracapsuloides bryosalmonae in fish kidneys was recognized by use of PCR and, except for fish from the stream Sillevad and the river Varde, infection was confirmed through lectin histochemistry. For PCR detection, DNA was extracted with a QIAamp DNA Mini Kit (QIAGEN) following the manufacturer's protocol. PCR was performed using $1 \mu \mathrm{l}$ of the crude DNA extract as template in $25 \mu \mathrm{l}$ reaction volumes containing 1 unit of Biotaq ${ }^{\mathrm{TM}}$ DNA Polymerase (Bioline DNA Technology) at $3.0 \mathrm{mM} \mathrm{MgCl}_{2}$ and the primers PKX3f and PKX4r at 1.0 $\mu \mathrm{M}$ (Kent et al. 1998). PCR was run in a Biometra T3000 Thermocycler (Biometra) under the following conditions: an initial denaturation at $94^{\circ} \mathrm{C}$ for $3 \mathrm{~min}$ followed by 35 cycles of denaturation at $94^{\circ} \mathrm{C}$ for $30 \mathrm{~s}$, annealing at $50^{\circ} \mathrm{C}$ for $30 \mathrm{~s}$, elongation at $72^{\circ} \mathrm{C}$ for $2 \mathrm{~min}$, and finally postelongation at $72^{\circ} \mathrm{C}$ for 6 min.

\section{ITS1 sequence analysis}

The internal transcribed spacer 1 (ITS1) of Tetracapsuloides bryosalmonae in fish kidneys was amplified by use of the forward primer Tetra_F7 (GAT ACG GTG AAA GGT GGT GCA) and the reverse primer Tetra_R1 (CAT CGA TAT ACG AGC CGA GGT A) designed to amplify the $T$. bryosalmonae ITS1 plus the adjacent part of the 18S rRNA gene. Initially, standard PCR was performed on the same DNA extract as above, but conditions were slightly different: an initial denaturation at $94^{\circ} \mathrm{C}$ for $3 \mathrm{~min}$ followed by 35 cycles of denaturation at $94^{\circ} \mathrm{C}$ for $30 \mathrm{~s}$, annealing at $60^{\circ} \mathrm{C}$ for $30 \mathrm{~s}$, elongation at $72^{\circ} \mathrm{C}$ for $30 \mathrm{~s}$, and finally post-elongation at $72^{\circ} \mathrm{C}$ for $5 \mathrm{~min}$. Some samples did not yield any visible band on an ethidium bromide-stained agarose gel following this first, standard PCR. Therefore, $1 \mu \mathrm{l}$ of the PCR product was used as template for a nested PCR. The nested PCR conditions were similar to the standard reaction, except that the annealing temperature was $52^{\circ} \mathrm{C}$ and the forward primer Tetra_F2 (CCA TCG TGA CAG GGA CTG AAC) and reverse primer Tetra_R3 (CAT TTC ACC TCT ACC CAC CCA) were designed to anneal internally to the PCR product produced in the standard PCR. In addition, a few small subunit (SSU) sequences were acquired in order to confirm whether the PCR products were of $T$. bryosalmonae origin. PCR products were purified by use of an Illustra GFX PCR
DNA and Gel Purification Kit (GE Healthcare) according to the manufacturer's instructions. PCR products were sequenced bi-directionally (Macrogen), using the same primers as for the PCR. ITS1 sequences were aligned using ClustalX (Larkin et al. 2007), and a maximum likelihood tree was constructed using MEGA5 (Tamura et al. 2011) with 2000 bootstrap replications and settings otherwise as default for the software. A sequence (FJ417077) from rainbow trout from the Czech Republic was used as outgroup for this analysis.

\section{RESULTS}

\section{External signs of PKD}

No wild fish examined showed any clear external clinical signs of PKD. However, at autopsy, a considerable number of fish had kidney abnormalities, indicating possible infection with Tetracapsuloides bryosalmonae. Gross kidney abnormalities ranged from discolouration (pale red) of slightly enlarged kidneys to heavily swollen greyish and spongy kidneys. At 2 sample sites (the streams Lindved and Elverdam), several brown trout had a kidney that was pale and grey-coloured and greatly swollen. Infected farmed rainbow trout showed clinical signs such as abdominal distension, discolouration of skin, and lethargy. These fish also had greatly swollen and discoloured kidneys. The prevalence of kidney abnormalities in brown trout with an obvious greycoloured, distended kidney (Fig. 2A) varied and was highest in the streams Lindved and Elverdam, exhibiting infection prevalence of 96 and $70 \%$, respectively. On the other hand, fish from both the stream Kalvemose and the river Varde exhibited no morphological signs of PKD.

\section{Histological changes in kidneys}

Histological investigations of kidneys from wild brown trout depicted various degrees of deviations from a healthy kidney, ranging from a normal appearance of the tissue (Fig. 3) to a marked distortion of renal structure (Figs. 4 to 7). The latter condition included disordered renal tissue and partial loss of the kidney tubules and glomeruli. The most prominent kidney tissue abnormality observed in brown trout (samples from the stream Elverdam, Figs. 5 to 8) was comparable in appearance to that of the farmed rainbow trout with clinical PKD (Fig. 4). 


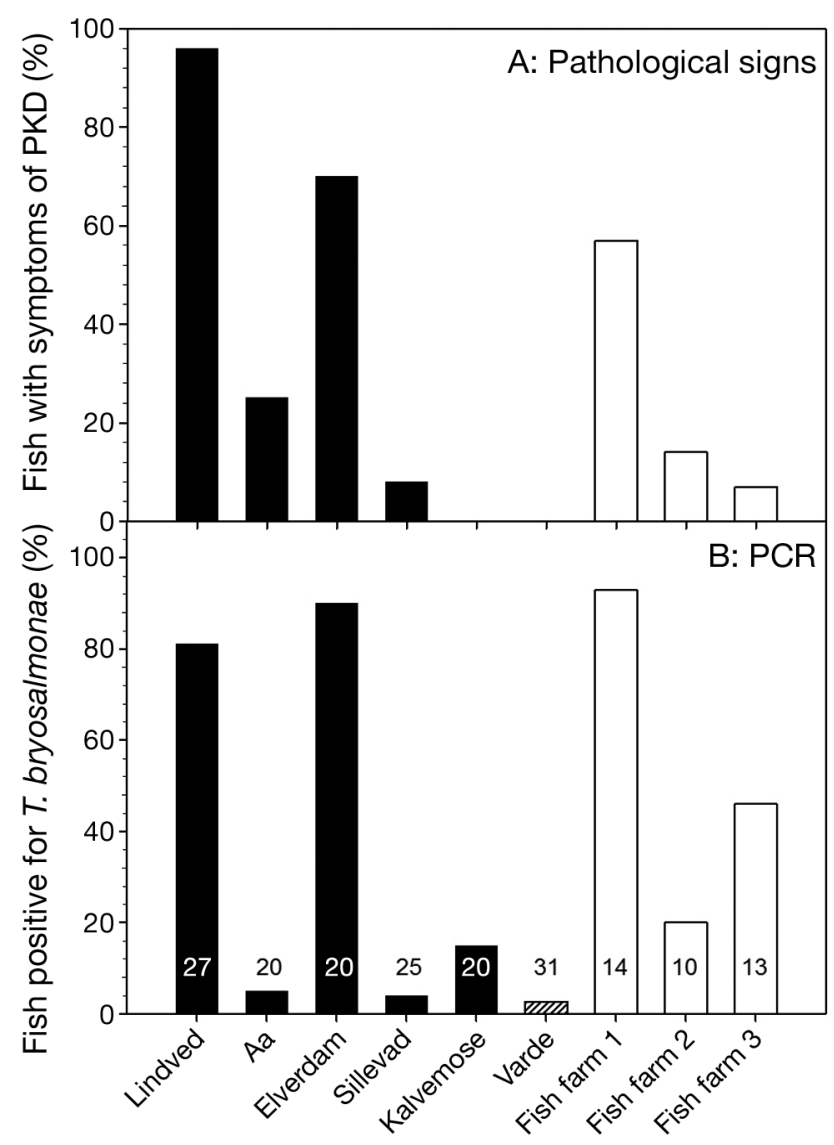

Fig. 2. Proliferative kidney disease (PKD) and Thymallus bryosalmonae in wild Salmo trutta (black bars) and S. salar (hatched bar) from 6 Danish streams and rivers and Oncorhynchus mykiss (white bars) from 3 fish farms. (A) Pathological signs of PKD, i.e. swollen and discoloured kidney and (in some cases also) lethargy, anaemia, and/or discoloured body. (B) Presence of T. bryosalmonae in kidneys as determined by PCR. Numbers on bars refer to sampling size (similar for A and B)

Haematoxylin-stained sections of brown trout kidneys showed presence of Tetracapsuloides bryosalmonae in the interstitium (Fig. 5). T. bryosalmonae stained clearly with lectin histochemistry and extrasporogonic stages of $T$. bryosalmonae could be observed in the kidney tissue of all infected fish (Figs. 4, 6 to 8). No T. bryosalmonae were visible in the control fish following lectin staining (Fig. 3). Histological examination showed that the kidney tissue damage and the presence of $T$. bryosalmonae were not evenly distributed in a fish kidney. This is exemplified in Figs. 7 \& 8, which show 2 adjacent areas of the same kidney section. One area of the kidney section showed extensive structural damage and numerous parasite stages (Fig. 7), whereas an adjacent area appeared normal with intact renal cells and tubules and only a single parasite (Fig. 8).

\section{Detection of Tetracapsuloides bryosalmonae by PCR}

Tetracapsuloides bryosalmonae could be detected by PCR at all sampling sites examined with prevalences ranging from 3 to $90 \%$ (Fig. 2B). The streams Lindved and Elverdam were the sampling sites with the highest prevalence and were thus comparable to the highest prevalence of $93 \%$ observed at one PKD-positive rainbow trout farm. The percentage of Atlantic salmon that was positive for $T$. bryosalmonae as determined by PCR was only $3 \%$ (1 fish out 31 ). However, the juvenile salmon may not have been fixed and stored adequately for preservation of kidney DNA (intact fish were put into $70 \%$ ethanol), and the prevalence of $T$. bryosalmonae may thus have been underestimated. In some cases a fish was $T$. bryosalmonaepositive as examined by PCR, but no $T$. bryosalmonae cells could be found through histology/ lectin histochemistry. On the other hand, all fish in which $T$. bryosalmonae cells were detected through histology were also positive for $T$. bryosalmonae as determined by PCR. Some samples that were negative by standard PCR (targeting SSU rDNA) yielded a positive signal when the nested PCR was applied to obtain ITS1 sequences.

\section{Sequence analysis}

A total of 16 complete or nearly complete Tetracapsuloides bryosalmonae ITS1 sequences were obtained from 3 different hosts (brown trout, Atlantic salmon, and rainbow trout): 3 from the stream Lindved, 2 from the stream Kalvehave, 6 from the stream Elverdam, 1 from the river Varde, and 4 from rainbow trout fish farms. Six unique sequences/ITS1 phylotypes (identified by asterisks in Fig. 9) were submitted to GenBank together with the other identical sequences (accession numbers JQ424918-JQ424933). ITS1 phylotypes appear to be related to geographic regions: All sequences from the 2 streams on Sealand were identical and so were the sequences from Funen (98\% similarity with the Sealand ITS1 phylotype). In streams and fish farms in Jutland, 4 different ITS1 phylotypes were identified. A simple phylogenetic analysis showed that the 4 ITS1 phylotypes found in Jutland clustered together, albeit with low support (Fig. 9), and that ITS1 sequences from the 3 main geographic areas (Jutland, Funen and Sealand) thus branched out separately. 

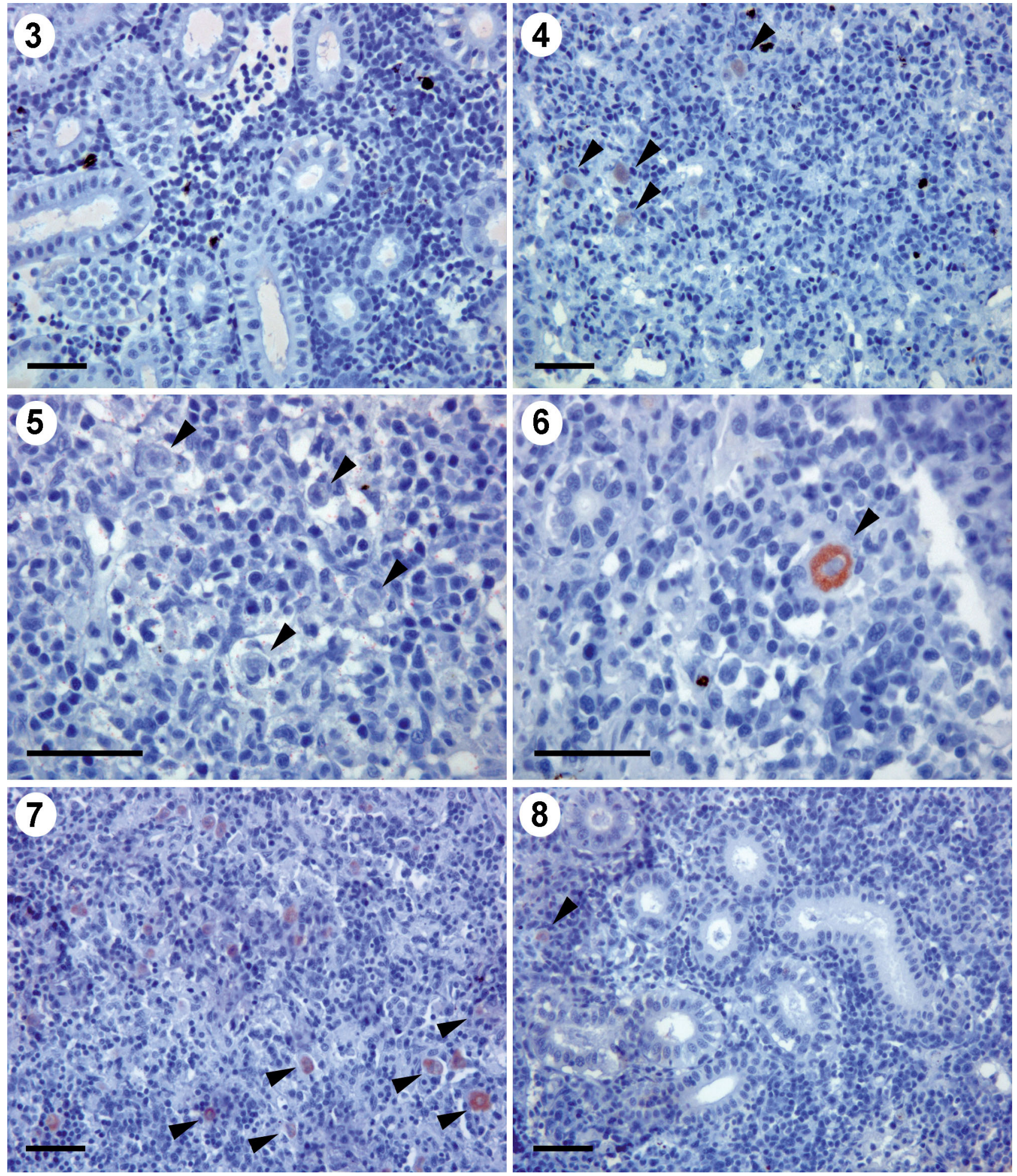

Figs. 3 to 8. Hematoxylin-stained sections of kidney from Danish 0+ salmonids. All sections except Fig. 5 were additionally stained with biotinylated GS-I lectin. Fig. 3. Uninfected Salmo trutta from tap water-fed hatchery. Fig. 4. Infected Oncorhynchus mykiss from fish farm with confirmed proliferative kidney disease (PKD) epidemic. Figs. 5 to 8 . Wild $S$. trutta from the stream Elverdam. Fig. 5. Degenerated tissue with many (unstained) parasites. Fig. 6. A single-stained parasite. Figs. 7 \& 8. Adjacent areas of a single tissue section. Fig. 7. Degenerated kidney tissue with many parasites. Fig. 8. Almost healthy appearance of tissue with a single-stained parasite. Arrowheads show Tetracapsuloides bryosalmonae extrasporogonic stages (not all parasites indicated); scale bars $=200 \mu \mathrm{m}$ 


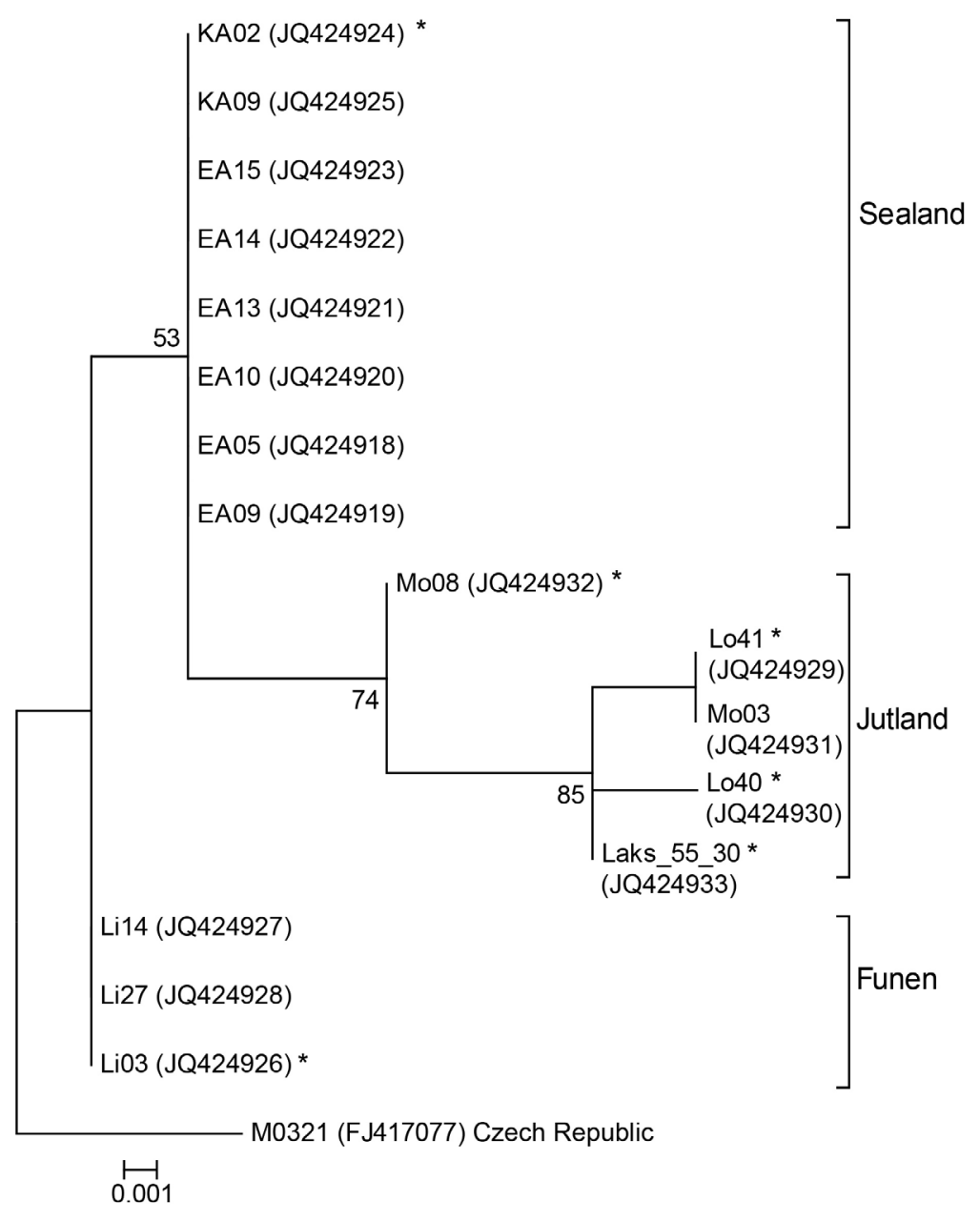

Fig. 9. Molecular phylogenetic tree (maximum likelihood) of 17 Tetracapsuloides bryosalmonae internal transcribed spacer 1 (ITS1) sequences from Danish salmonids, including a sequence from the Czech Republic serving as outgroup. There were a total of 355 positions in the final alignment. Numbers at nodes represent bootstrap values when above $50 \%$. Codes at branches are isolate numbers (KA, the stream Kalvemose; EA, the stream Elverdam; Li, the stream Lindved; Laks, wild Salmo salar; Lo and Mo, farmed Oncorhynchus mykiss) followed by GenBank accession number in brackets. Unique sequences are marked with asterisks
(AJ639977). If a varying number of microsatellite (GTG GGA) repeats is disregarded, isolate EA05 matched, among other isolates, a sequence isolate from rainbow trout in Italy (AJ640025). Among the Jutland ITS1 sequences, one isolate (Mo08 from rainbow trout) was $100 \%$ identical to a sequence isolated from Atlantic salmon in Scotland (AJ639960) and $98 \%$ identical to, among others, a Tetracapsuloides bryosalmonae ITS1 sequence from rainbow trout from Italy (AJ640035). Isolate Lo40 (also from rainbow trout) was $96 \%$ similar to sequences from rainbow trout from Italy (AJ640052) and France (AJ64 0034). Finally, isolate Laks_55_30 (from Atlantic salmon) showed 99\% similarity with an ITS1 sequence obtained from rainbow trout (AJ640052) from Italy.

A few partial Tetracapsuloides bryosalmonae SSU rDNA sequences were also obtained during the present study (for confirmation of the nature of PCR products obtained during PCR-based detection of parasites). These were up to $682 \mathrm{bp}$ long, exhibited no variation, and matched $100 \%$, among others, 3 corresponding sequences originating from Atlantic salmon in Norway and the potential alternate bryozoan host species Fredericella sultana, from the UK, and Cristatella mucedo, from Ohio, USA (GenBank accession numbers EU570235, FJ981823, and AJ133417, respectively).

\section{DISCUSSION}

type from the streams Lindved and Aa (Funen) was $100 \%$ identical to sequences from, among others, brown trout from Switzerland (AJ640020) and the bryozoan Fredericella sultana from England (AJ639986). On the other hand, the ITS1 phylotypes from Sealand and most of the Jutland isolates did not yield any exact matches through BLAST searches. The sequences from Sealand (e.g. isolate EA05) were 99\% similar (one nucleotide difference) to sequences isolated from rainbow trout in Italy (AJ640033), F. sultana in Germany (AJ639992) and brown trout in England

\section{First reported case of Tetracapsuloides bryosalmonae in wild Danish salmonids}

This first survey of Tetracapsuloides bryosalmonae in wild Danish salmonids shows that the parasite is widespread in natural streams in Denmark. The presence of $T$. bryosalmonae is demonstrated through the macroscopic signs of PKD in infected brown trout in 2 streams, Lindved and Elverdam. Furthermore, the existence of $T$. bryosalmonae in brown trout kidney cells was demonstrated by histo- 
logy and lectin histochemistry, and finally T. bryosalmonae genetic material was detected in fish kidneys by PCR. This study thus documents that wild brown trout are to a large extent infected with $T$. bryosalmonae and in some cases exhibit pathological changes that are comparable to those of farmed rainbow trout suffering from PKD. No dead fish were observed in association with the sampling, but mortalities cannot be excluded since streams were not long-term monitored for this purpose. Besides, samples were taken in October/November, when effects of PKD were probably declining.

The finding that Tetracapsuloides bryosalmonae is common in wild Danish salmonids may not be surprising, considering that PKD has been observed in Danish rainbow trout farms for at least 2 decades (Olesen 1984, Buchmann et al. 1995), and furthermore, $T$. bryosalmonae occurs extensively in salmonid fish (Feist \& Bucke 1993, El-Matbouli \& Hoffmann 2002, Mo et al. 2011) and in bryozoans (Anderson et al. 1999, Okamura et al. 2001) in the neighbouring countries: the UK, Germany, and Norway. There is little doubt that $T$. bryosalmonae is widespread in nature in Denmark. It was possible to detect the parasite in all 6 freshwater streams and rivers in the present study and in particular in 2 of the streams, Lindved and Elverdam, where it had high prevalence, 81 and $90 \%$, respectively, as determined by PCR (Fig. 2B). One must note that the detection of T. bryosalmonae in fish with low infection intensity is subject to methodological limitations. Usually only a small piece of kidney is used for parasite detection, and the parasite cells appear to be unevenly distributed in the kidney and can, therefore, easily be overlooked both by PCR and histological examination. This is exemplified in Figs. $7 \& 8$ in which 2 adjacent areas of the same kidney section were morphologically different, ranging from highly deteriorated kidney tissue with many $T$. bryosalmonae cells to a seemingly healthy kidney with intact renal tubules and only a few $T$. bryosalmonae cells.

\section{ITS1 phylogeny}

The Tetracapsuloides bryosalmonae ITS1 sequences from the 3 main geographic areas (i.e. the Jutland peninsula and the islands of Sealand and Funen) tended to cluster separately in the phylogenetic analysis. Such a biogeographic pattern is not the general picture for this parasite (Henderson \& Okamura 2004). On the contrary, identical ITS phylotypes usually occur in host species from far separate geographic localities. The possibility cannot be excluded that the geographic pattern of ITS1 sequences observed here may have been biased by a relatively low number of localities sampled, since the relative differences between sequences were indeed small. Furthermore, it must be stressed that PCR products were not cloned prior to sequencing, and the choice of primers may, therefore, have led to preferential amplification of certain phylotypes.

\section{Effects of PKD in wild fishes}

It is clear now from several studies that Tetracapsuloides bryosalmonae is widespread in wild hosts in both Europe and North America and that many wild salmonids suffer from PKD (Wahli et al. 2007, Okamura et al. 2011). While PKD constitutes a serious problem for freshwater production of salmonids in Europe and North America (Hedrick et al. 1993, Okamura et al. 2011), the effects of $T$. bryosalmonae infections on wild fish populations are still debatable. Several investigations have noted the presence of $T$. bryosalmonae infections and discussed the possible connection with decreases in populations of infected fish. In Switzerland, it has been suggested that recent decreases in brown trout populations were caused by PKD (Wahli et al. 2002, 2007). A similar scenario is thought to be the case for Atlantic salmon in Norway (Sterud et al. 2007), and (Kristmundsson et al. 2010) hypothesize that PKD may play a significant role in the recent decline in Arctic charr populations in Iceland. Indeed, there is justification for concluding that PKD is an important factor for these declines in trout populations, and it is to be expected that the consequences of PKD will become more severe if water temperatures are to increase in the future (Burkhardt-Holm \& Scheurer 2007, Okamura et al. 2011).

On the other hand, an infection with Tetracapsuloides bryosalmonae does not always necessarily lead to clinical PKD, and even when it does, fish may survive the infection (Hedrick et al. 1993). High mortalities due to PKD in fish farms are typically associated with secondary infections (Feist \& Bucke 1993), and while PKD has weakened the fish, it may be a combination of $\mathrm{PKD}$, secondary infections, and adverse environmental conditions that causes the mortality. Thus, existing information may be interpreted such that $T$. bryosalmonae infections are often less severe for wild fish than for farmed fish kept at high stock densities. For example, a recent study showed that more than half of the wild Atlantic 
salmon and brown trout examined in Norway by real-time PCR were positive for T. bryosalmonae, but no fish had evident clinical or histological signs of PKD (Mo et al. 2011). This is similar to what was found in some streams in the present study. There may be several explanations why $T$. bryosalmonae is not always detrimental for some wild host fishes. First of all, the development and effects of PKD is highly dependent on temperature (de Kinkelin \& Loriot 2001, Bettge et al. 2009) and on the timing of the infection (Ferguson 1981). Furthermore, the effects of this parasite vary with host species, brown trout apparently being, at least in some studies, among the less severely infected hosts (Wahli et al. 2002, Beraldo et al. 2006, Kristmundsson et al. 2010). Nevertheless, the present study demonstrates that infection with $T$. bryosalmonae is indeed associated with pathological changes in brown trout and that this species is severely affected by the infection.

Even though a relation between PKD and stock declines of brown trout has been suggested (Wahli et al. 2007), mass mortalities due to this disease are rarely observed in wild salmonids with the exception of the observations made by Sterud et al. (2007). Recorded cases are typically either subclinical infections or cases with clinical signs, where no mortality could be documented (Wootten \& McVicar 1982, Feist \& Bucke 1993). However, mortalities in the wild are likely to be overlooked unless a large number of fish are dying simultaneously. Clearly, more investigations are required to conclude finally on the effects of Tetracapsuloides bryosalmonae on wild salmonid fish, and methods should be developed to document those effects more accurately.

Acknowledgements. We are indebted to the staff at Fyns Laksefisk Elsesminde, M. Carøe (DTU-AQUA), and P. W. Henriksen (Limno Consult), for help in sampling and electrofishing. Financial support was granted by the Villum Kann Rasmussen Foundation.

\section{LITERATURE CITED}

Anderson CL, Canning EU, Okamura B (1999) Molecular data implicate bryozoans as hosts for PKX (Phylum Myxozoa) and identify a clade of bryozoan parasites within the Myxozoa. Parasitology 119:555-561

> Arkush KD, Hedrick RP (1990) Experimental transmission of PKX, the causative agent of proliferative kidney disease, to three species of Pacific salmon. J Appl Ichthyol 6: 237-243

Beraldo P, Berton D, Giavenni R, Galeotti M (2006) First report on proliferative kidney disease (PKD) in marble trout (Salmo trutta marmoratus, Cuvier 1817). Bull Eur Assoc Fish Pathol 26:143-150
Bettge K, Segner H, Burki R, Schmidt-Posthaus H, Wahli T (2009) Proliferative kidney disease (PKD) of rainbow trout: temperature- and time-related changes of Tetracapsuloides bryosalmonae DNA in the kidney. Parasitology 136:615-625

Braden LM, Prosperi-Porta G, Kim E, Jones SRM (2010) Tetracapsuloides bryosalmonae in spawning pink salmon, Oncorhynchus gorbuscha (Walbaum), in the Quinsam River, British Columbia, Canada. J Fish Dis 33: 617-621

Buchmann K, Bresciani J (1997) Parasitic infections in pondreared rainbow trout Oncorhynchus mykiss in Denmark. Dis Aquat Org 28:125-138

Buchmann K, Uldal A, Lyholt HCK (1995) Parasite infections in Danish trout farms. Acta Vet Scand 36:283-298

Bucke D, Feist SW, Clifton-Hadley RS (1991) The occurrence of proliferative kidney disease (PKD) in cultured and wild fish: further investigations. J Fish Dis 14: 583-588

$>$ Burkhardt-Holm P, Scheurer K (2007) Application of the weight-of-evidence approach to assess the decline of brown trout (Salmo trutta) in Swiss rivers. Aquat Sci 69: 51-70

Canning EU, Curry A, Feist SW, Longshaw M, Okamura B (1999) Tetracapsula bryosalmonae n. sp. for PKX organism, the cause of PKD in salmonid fish. Bull Eur Assoc Fish Pathol 19:203-206

Canning EU, Tops S, Curry A, Wood TS, Okamura B (2002) Ecology, development and pathogenicity of Buddenbrockia plumatellae Schröder, 1910 (Myxozoa, Malacosporea) (syn. Tetracapsula bryozoides) and establishment of Tetracapsuloides n. gen. for Tetracapsula bryosalmonae. J Eukaryot Microbiol 49:280-295

Castagnaro M, Marin M, Ghittino C, Hedrick RP (1991) Lectin histochemistry and ultrastructure of rainbow trout Oncorhynchus mykiss kidneys affected by proliferative kidney disease. Dis Aquat Org 10:173-183

Clifton-Hadley RS, Bucke D, Richards RH (1984) Proliferative kidney disease of salmonid fish: a review. J Fish Dis 7:363-377

> de Kinkelin P, Loriot B (2001) A water temperature regime which prevents the occurrence of proliferative kidney disease (PKD) in rainbow trout, Oncorhynchus mykiss (Walbaum). J Fish Dis 24:489-493

Ellis AE, McVicar AH, Munro ALS (1982) A preliminary report on the epidemiology of proliferative kidney disease in brown trout (Salmo trutta) and Atlantic salmon parr (S. salar) in Scotland. Bull Eur Assoc Fish Pathol 2: 13-15

> El-Matbouli M, Hoffmann RW (2002) Influence of water quality on the outbreak of proliferative kidney diseasefield studies and exposure experiments. J Fish Dis 25: 459-467

Feist SW, Bucke D (1993) Proliferative kidney disease in wild salmonids. Fish Res 17:51-58

> Ferguson HW (1981) The effects of water temperature on the development of proliferative kidney disease in rainbow trout, Salmo gairdneri Richardson. J Fish Dis 4: 175-177

> Grabner DS, El-Matbouli M (2008) Transmission of Tetracapsuloides bryosalmonae (Myxozoa: Malacosporea) to Fredericella sultana (Bryozoa: Phylactolaemata) by various fish species. Dis Aquat Org 79:133-139

Hedrick AR, Kent ML, Rosemark R, Manzer D (1984) Occurrence of proliferative kidney disease (PKD) among 
Pacific salmon and steelhead trout. Bull Eur Assoc Fish Pathol 4:34-37

Hedrick RP, MacConnell E, de Kinkelin P (1993) Proliferative kidney disease of salmonid fish. Annu Rev Fish Dis 3: 277-290

Henderson M, Okamura B (2004) The phylogeography of salmonid proliferative kidney disease in Europe and North America. Proc R Soc Lond B Biol Sci 271: 1729-1736

Kent ML, Khattra J, Hervio DML, Devlin RH (1998) Ribosomal DNA sequence analysis of isolates of the PKX myxosporean and their relationship to members of the genus Sphaerospora. J Aquat Anim Health 10:12-21

Kristmundsson A, Antonsson T, Arnason E (2010) First record of proliferative kidney disease in Iceland. Bull Eur Assoc Fish Pathol 30:35-40

Larkin MA, Blackshields G, Brown NP, Chenna R and others (2007) Clustal W and clustal X version 2.0. Bioinformatics 23:2947-2948

Longshaw M, Feist SW, Canning EU, Okamura B (1999) First identification of PKX in bryozoans from the United Kingdom-molecular evidence. Bull Eur Assoc Fish Pathol 19:146-148

MacConnell E, Peterson JD (1992) Proliferative kidney disease in feral cutthroat from a remote Montana reservoir: a first case. J Aquat Anim Health 4:182-187

Marcus E (1940) Mosdyr (Bryozóa eller Polyzóa). Dan Fauna 46:1-401

Mo TA, Kaada I, Joranlid AK, Poppe TT (2011) Occurrence of Tetracapsuloides bryosalmonae in the kidney of smolts of Atlantic salmon (Salmo salar) and sea trout $(S$. trutta). Bull Eur Assoc Fish Pathol 31:151-155

> Morris DJ, Longshaw M, Adams A (2003) California golden trout Oncorhynchus mykiss aguabonita are susceptible to proliferative kidney disease. J Aquat Anim Health 15: 184-187

Okamura B, Anderson CL, Longshaw M, Feist SW, Canning EU (2001) Patterns of occurrence and 18S rDNA sequence variation of PKX (Tetracapsula bryosalmonae), the causative agent of salmonid proliferative kidney disease. J Parasitol 87:379-385

Okamura B, Hartikainen H, Schmidt-Posthaus H, Wahli T (2011) Life cycle complexity, environmental change and the emerging status of salmonid proliferative kidney disease. Freshw Biol 56:735-753

Olesen NJ (1984) PKD i 1984. Ferskvandsfiskeribladet 83: 126-129 (in Danish)

Editorial responsibility: Dieter Steinhagen, Hannover, Germany
Peeler EJ, Feist SW, Longshaw M, Thrush MA, St-Hilaire S (2008) An assessment of the variation in the prevalence of renal myxosporidiosis and hepatitis in wild brown trout, Salmo trutta L., within and between rivers in South-West England. J Fish Dis 31:719-728

Roberts JJ, Shepherd CJ (1974) Handbook of trout and salmon diseases, Fishing News, Surrey

- Seagrave CP, Bucke D, Hudson EB, McGregor D (1981) A survey of the prevalence and distribution of proliferative kidney disease (PKD) in England and Wales. J Fish Dis 4: 437-439

Sterud E, Forseth T, Ugedal O, Poppe TT and others (2007) Severe mortality in wild Atlantic salmon Salmo salar due to proliferative kidney disease (PKD) caused by Tetracapsuloides bryosalmonae (Myxozoa). Dis Aquat Org 77 : 191-198

Tamura K, Peterson D, Peterson N, Stecher G, Nei M, Kumar S (2011) MEGA5: molecular evolutionary genetics analysis using maximum likelihood, evolutionary distance, and maximum parsimony methods. Mol Biol Evol 28: 2731-2739

> Tops S, Lockwood W, Okamura B (2006) Temperaturedriven proliferation of Tetracapsuloides bryosalmonae in bryozoan hosts portends salmonid declines. Dis Aquat Org 70:227-236

Von Gersdorff Jørgensen L, Heinecke RD, Kania P, Buchmann K (2008) Occurrence of gyrodactylids on wild Atlantic salmon, Salmo salar L., in Danish rivers. J Fish Dis 31:127-134

Wahli T, Knuesel R, Bernet D, Segner H and others (2002) Proliferative kidney disease in Switzerland: current state of knowledge. J Fish Dis 25:491-500

> Wahli T, Bernet D, Steiner PA, Schmidt-Posthaus H (2007) Geographic distribution of Tetracapsuloides bryosalmonae infected fish in Swiss rivers: an update. Aquat Sci 69:3-10

Wiebach F (1960) Bryozoa. In: Brohmer P, Ehrmann P, Ulmer G (eds) Die Tierwelt Mitteleuropas. Quelle \& Meyer, Leipzig, p 1-56

Wood TS (2002) Freshwater bryozoans: a zoogeographical reassessment. In: Jackson PNW, Buttler CJ, Jones MES (eds) Bryozoan studies 2001. AA Balkema, Lisse, p 339-345

Wootten R, McVicar AH (1982) Some preliminary observations on proliferative kidney disease in wild brown trout, Salmo trutta L., in a Scottish stream. Bull Eur Assoc Fish Pathol 2:60-62

Submitted: January 24, 2012; Accepted: July 3, 2012

Proofs received from author(s): September 21, 2012 